\title{
Selibat Atau Menikah?: Petunjuk-Petunjuk Menentukan Pilihan Berdasarkan Studi Eksposisional 1 Korintus 7
}

\section{Celibacy or Marriage ?: Instructions for Making Decision Based on Expositional Study of 1 Corinthians 7}

\author{
Elisabeth Natallina \\ Gereja Kristen Abdiel (GKA) Gloria, Surabaya \\ Korespondensi: elisabethnatallina@gmail.com
}

\begin{abstract}
Abstrak: Pergulatan batin memutuskan untuk menikah atau selibat merupakan pergumulan sebagian jemaat Tuhan, khususnya anak-anak muda. Memilih satu dari dua pilihan tersebut kadang menjadi sulit dengan beberapa kompleksitas yang ada, salah satunya karena kurangnya pemahaman akan prinsip-prinsip Alkitab berkaitan dengan isu ini. Sebagian orang percaya kurang mengerti petunjuk-petunjuk Alkitabiah yang dapat membantu mereka dalam masa menggumulkan untuk menikah atau selibat. Sementara pergumulan ini terus berlanjut, data menyatakan bahwa tingkat kelajangan meningkat kuantitasnya baik secara global maupun nasional. Baik akan menikah maupun selibat, keputusan untuk menentukan hal tersebut menurut Paulus haruslah berdasarkan pada karunia masing-masing. Tulisan ini akan memaparkan bahwa untuk mengenali karunia seseorang, ada beberapa petunjuk yang dapat dipelajari dari nasihat Paulus dalam 1 Korintus 7 soal status hidup, khususnya selibat, yaitu tentang perhatian hidup, dorongan seksualitas, dan keyakinan hati.
\end{abstract}

Kata-kata kunci: Menikah, Selibat, Kelajangan, 1 Korintus 7

Abstract: The inner struggle to decide whether to marry or be celibate is a struggle for some Christians, especially young people. Choosing one of these two options can be difficult with some complexity, one of which is due to a lack of understanding of Bible's principles related to this issue. Some believers do not understand the biblical instructions that can help them in their struggle to be married or celibate. While this struggle continues, data shows that quantity level of singleness is increasing globally in the world and in Indonesia itself. Either to be married or celibate, the decision to determine between these two options, according to Paul, must be based on their gifts. This paper will explain the instructions that can be learned from Paul's advice in 1 Corinthians 7 to make decisions about the status of life, especially celibacy.

Keywords: Marriage, Celibacy, Singleness, 1 Corinthians 7 


\section{PENDAHULUAN}

"Saya harus menikah atau selibat?" Pertanyaan ini sering kali menjadi perenungan sekaligus pergumulan bagi sebagian pemudapemudi Kristen yang masih lajang. Menjawab pertanyaan tersebut juga menjadi pergumulan bagi gereja yang hendak mengarahkan jemaatnya untuk mengambil sebuah keputusan besar soal status hidup mereka. Memilih untuk menikah atau selibat merupakan sebuah keputusan hidup yang tidak gampang bagi sebagian orang. Menentukan pilihan atas pergulatan batin ini dapat menjadi proses yang kompleks. Kompleksitas pergumulan ini disebabkan oleh tiga hal. Pertama, adanya asumsi masyarakat bahwa hidup selibat adalah status yang kurang lazim, atau bahkan second class. Tidak sedikit yang berpikir bahwa manusia diciptakan untuk menikah dan berpasangan. Sebagian orang Kristen bahkan berpikir bahwa manusia akan menjalani hidup yang "normal" apabila ia menikah, sebaliknya hidupnya akan menjadi "tidak normal" apabila selibat. ${ }^{1}$ Kedua, mencari pasangan menjadi proses hidup yang gampang-gampang susah. Bagi sebagian orang, keputusan untuk menikah tidak menjadi sulit karena dengan sangat natural bahkan tanpa usaha yang keras mereka mendapatkan pasangan hidup. Namun, bagi sebagian yang lain, mencari pasangan hidup menjadi proses yang susah karena mereka ragu-ragu untuk menetapkan pilihan, atau sulit mendapatkan pasangan yang sesuai dengan ekspektasi dan kriteria mereka. Ketiga, sebagian orang percaya bingung untuk memilih menikah atau selibat karena mereka sendiri kurang memahami dengan jelas bagaimana prinsip Alkitab soal isu ini. Sebagian orang percaya kurang memahami apa saja petunjuk-petunjuk untuk memutuskan hidup selibat menurut prinsip Alkitab.

Isu soal kelajangan bukan hanya dialami oleh gereja, melainkan telah menjadi fenomena global dan nasional. Secara global, jumlah orang lajang terus meningkat dari waktu ke

${ }^{1}$ Yusak Tridarmanto, "Menikah? Baik. Tidak? Lebih Baik: Suatu Telaah Teologis atas Respon Rasul Paulus terhadap Tendensi Hidup Selibat di dalam 1 Korintus 7," Gema Teologi 33 no. 1 (April 2009): 3. waktu. Karel Karsten Himawan, Matthew Bambling, dan Sisira Edirippulige dalam penelitian mereka yang berjudul "What Does It Mean to Be Single in Indonesia" memaparkan data yang mengherankan soal pertumbuhan jumlah orang lajang secara global, yaitu sebagai berikut: ${ }^{2}$ di Amerika, persentase orang yang belum menikah (lajang) berusia di atas 35 tahun telah meningkat tajam menjadi hampir $14 \%$ untuk pria dan lebih dari $10 \%$ untuk wanita selama periode 1980 hingga 2010. Pola serupa juga ditemukan di Australia, di mana tingkat pernikahan turun sekitar 7,8\% selama 2012 hingga 2015, diikuti dengan peningkatan hidup bersama sebelum menikah (yang selanjutnya akan dipakai istilah kumpul $k e b o^{3}$ ) hingga $81 \%$. Hal ini diikuti fenomena melambatnya usia seseorang untuk menikah. Pada tahun 1990, usia rata-rata pernikahan di Australia adalah 28,2 tahun untuk pria dan 25,9 tahun untuk wanita (Biro Statistik Australia, 2012), sedangkan pada 2015, usia seseorang menikah adalah rata-rata 31,8 tahun untuk pria dan 29,8 tahun untuk wanita (Australian Bureau of Statistics, 2016). Tren serupa juga terjadi di Eropa. Menurut survei pemerintah di Inggris pada 2008, 51\% orang dewasa di Inggris dan Wales berada dalam status lajang. ${ }^{4}$

Peningkatan jumlah orang yang membujang bukan hanya merupakan realitas di negaranegara Barat melainkan juga dalam konteks yang lebih dekat, yaitu di Asia. Para lajang di Asia cenderung diperlakukan secara berbeda oleh masyarakat dibandingkan dengan para

\footnotetext{
${ }^{2}$ Karel Karsten Himawan, Matthew Bambling, dan Sisira Edirippulige, "What Does It Mean to Be Single in Indonesia? Religiosity, Social Stigma, and Marital Status Among Never-Married Indonesian Adults," SAGE Open (Juli-September 2018): 1, https://doi. org/10.1177/2158244018803132.

${ }^{3}$ Kumpul kebo merupakan istilah tidak baku namun sudah umum digunakan oleh masyarakat Indonesia yang artinya sama dengan kohabitasi, yaitu hidup dan tinggal bersama seperti pasangan suami istri namun tidak memiliki ikatan pernikahan yang sah.

${ }^{4}$ Kathryn Wehr, "Virginity, Singleness and Celibacy: Late Fourth-Century and Recent Evangelical Visions of Unmarried Christians," Theology \& Sexuality 17 no. 1 (Januari 2011): 76, diakses 2 Oktober 2018, https://doi. org/10.1558/tse.v17i1.75.
} 
lajang di negara-negara Barat. Di Barat, hidup bersama sebelum menikah merupakan hal yang dianggap biasa. Sedangkan di Asia, kumpul kebo merupakan suatu tindakan amoral. Status legal pernikahan dianggap sebagai sesuatu yang penting. Oleh karena itu, masyarakat di Asia lebih dituntut untuk memiliki status pernikahan dibandingkan dengan di Barat. Namun walaupun demikian, angka tingkat kelajangan di Asia juga meningkat. Jumlah kelajangan tertinggi di Asia ditemukan di Taiwan, diikuti oleh Korea Selatan, Jepang, dan Myanmar. ${ }^{5}$ Selain negara-negara tersebut, China, Singapura, Malaysia, dan Indonesia juga merupakan negara-negara yang memiliki jumlah kelajangan tertinggi di Asia. $^{6}$

Walaupun konteksnya berbeda dengan Barat, fakta di Indonesia menyebutkan bahwa orangorang yang membujang mengalami tantangan yang berat akibat stigma negatif yang kerap menjadi label oleh masyarakat. Khususnya bagi perempuan lajang di Indonesia, stigmatisasi bagi mereka lebih tinggi daripada kepada pria. Julukan yang diberikan kepada para perempuan lajang adalah "perawan tua" dan "lajang kota." Label yang lebih menyedihkan ditujukan kepada kaum lajang adalah "jomblo tidak laku" dan "bujang lapuk." Labelisasi tersebut menimbulkan tekanan psikologis yang cukup berat. Mereka secara sosial dianggap terlalu selektif atau berorientasi pada diri sendiri. ${ }^{8}$ Tekanan-tekanan tersebut menyebabkan perasaan tidak mampu dan rendah diri. Tingkat penolakan sosial tertentu terhadap para lajang di Indonesia dapat membawa dampak yang cukup besar bagi kesejahteraan mereka.

${ }^{5}$ Karel Karsten Himawan, Matthew Bambling, dan Sisira Edirippulige, "The Asian Single Profiles: Discovering Many Faces of Never Married Adults in Asia," Journal of Family Issues (2018): 2, diakses 2 Oktober 2018, https://doi. org/10.1177/0192513X18789205.

${ }^{6}$ Ibid.

${ }^{7}$ Himawan, Bambling, dan Edirippulige, "What Does It Mean," 4.

${ }^{8}$ Ibid.
Berkaca dari kondisi di atas, tema soal kelajangan seyogyanya menjadi perhatian bagi para pelayan Tuhan. Namun sayangnya, menurut Febriana meningkatnya kelajangan di kota-kota besar di Indonesia justru tidak mendapat tanggapan yang serius dari gereja. ${ }^{9}$ Gereja cukup serius mengajarkan banyak prinsip soal menikah, tetapi kurang memberi pengajaran yang cukup soal selibat. Wehr mengatakan bahwa gereja-gereja Injili di Barat mengajarkan untuk tetap tidak menikah di usia muda. ${ }^{10}$ Sementara itu, hampir setengah dari orang dewasa yang masih bujang bertanya-tanya apa makna kelajangan bagi mereka. ${ }^{11}$ Penjelasan alkitabiah soal topik selibat di gereja tentunya menjadi kebutuhan bagi jemaat Tuhan. Sebagian orang Kristen berpikir bahwa menikah adalah status yang harus dikejar. Di sisi lain, sebagian orang percaya justru sangat meninggikan kelajangan seolah-olah panggilan selibat lebih suci daripada menikah. Tulisan ini akan menunjukkan bahwa menurut Paulus, memutuskan untuk menikah atau selibat bukan soal mana yang lebih suci melainkan mana yang lebih sesuai dengan karunia masing-masing. Secara lebih detail, artikel ini akan menjelaskan beberapa poin: pertama, menilik faktor-faktor yang menyebabkan meningkatnya tingkat kelajangan pada masa kini (di Asia dan Indonesia) dan masa lampau (di jemaat Korintus). Kedua, menemukan prinsip-prinsip teologis yang dapat menjadi petunjuk bagi mereka yang menggumulkan soal menikah atau selibat berdasarkan studi eksposisional 1 Korintus 7. Ketiga, memberikan implikasi praktis berupa tiga peran yang dapat dilakukan oleh gereja untuk menolong jemaatnya yang menggumulkan soal status hidup mereka.

\section{FAKTOR-FAKTOR PENYEBAB MENINGKATNYA KELAJANGAN}

Walaupun konteksnya berbeda, isu soal selibat atau menikah telah menjadi pergumulan

\footnotetext{
${ }^{9}$ Mariani Febriana, "Lajang dalam Gereja dan Pelayanan,” Jurnal Theologi Aletheia 17, no. 8 (Maret 2015): 31.

${ }^{10} \mathrm{Wehr}$, "Virginity, Singleness and Celibacy," 76.

${ }^{11}$ Ibid.
} 
pada masa kini dan juga masa lampau, khususnya di jemaat Korintus. Pada masa kini ada beberapa faktor penyebab yang membuat angka kelajangan meningkat. Pilihan seseorang untuk akhirnya tidak menikah pada masa kini di Asia dan Indonesia lebih banyak dipengaruhi oleh faktor sosial, ekonomi, dan pendidikan. Sedangkan di masa lampau, penyebab jemaat Korintus memutuskan untuk selibat lebih banyak dipengaruhi oleh ajaran.

\section{Penyebab Kelajangan di Asia}

Pada masa kini, setiap negara memiliki kondisi masing-masing yang menjadi faktor-faktor penyebab meningkatnya jumlah kelajangan. Di Jepang, jumlah orang yang melajang mengalami peningkatan disebabkan jumlah jam kerja yang panjang baik bagi pria maupun wanita. ${ }^{12}$ Sebuah studi mengungkapkan bahwa jam kerja yang begitu panjang di Jepang, di samping mengurangi waktu anak-anak muda untuk bersosialisasi, diyakini juga dapat mengurangi kepuasan pernikahan di antara pekerja yang menikah yang pada akhirnya menampilkan citra perkawinan negatif kepada para lajang. Selain itu, seks pranikah yang lebih dapat diakses dengan gampang di Jepang membuat para muda enggan untuk menikah. Oleh karena itu, ada peningkatan jumlah orang yang melajang di Jepang. Pada 2015, usia rata-rata orang yang menikah adalah 31,5 tahun untuk pria dan 29,4 untuk wanita. Hal ini sangat berbeda dengan tahun 1970 , pria mulai menikah pada usia 27,5 tahun dan wanita melakukannya pada usia 24,7 tahun. ${ }^{13}$ Di Jepang, status lajang mendominasi kalangan wanita. Pada 2010, hampir $40 \%$ wanita berusia di atas 30 tahun masih melajang, dan sekitar $15 \%$ hingga $20 \%$ dari mereka kemungkinan akan tetap melajang ketika mereka mencapai usia 49 tahun. ${ }^{14}$

Di China, tren melajang juga dilakukan oleh lebih banyak orang dibanding tahun-tahun

${ }^{12}$ Himawan, Bambling, dan Edirippulige, "The Asian Single Profiles," 4-5.

${ }^{13}$ Ibid.

${ }^{14}$ Ibid. sebelumnya. Sebenarnya, negara ini cukup menciptakan iklim yang mendukung masyarakatnya menikah. Misalnya, pada 1950 China mengumumkan bahwa kumpul kebo merupakan suatu tindakan yang melanggar hukum. ${ }^{15}$ Hal ini membuat masyarakat China dituntut untuk menikah bila ingin memiliki teman hidup. Namun, ada sebuah fakta yang menarik. Himawan, Bambling, dan Edirippulige menjelaskan bahwa para pria di China umumnya sekolah dengan tingkat pendidikan yang memadai sehingga memiliki karier dan status ekonomi yang baik (high-end man), kemudian mereka biasanya menikah dengan wanita dengan status pendidikan dan ekonomi yang lebih rendah (lower woman). ${ }^{16}$ Kondisi demikian sangat lazim. Namun belakangan ini, ada sedikit transisi yang menyebabkan perubahan. Para perempuan di China mulai mengejar pendidikan dan status ekonomi yang tinggi sehingga menjadikan mereka sebagai perempuan-perempuan dengan kedudukan yang tinggi (high-end woman). ${ }^{17}$ Akibatnya, para perempuan demikian kesulitan untuk mencari pria yang status pendidikan dan ekonominya lebih tinggi daripada mereka. Hasilnya, sebuah penelitian yang dilakukan Qian tahun 2014 menyebutkan makin banyak high-end women and low-end men yang melajang. ${ }^{18}$

\section{Penyebab Kelajangan di Indonesia}

Di Indonesia, tingkat kelajangan juga meningkat cukup tinggi. Menurut data dari Badan Pusat Statistik pada 2010, usia seseorang menikah di Indonesia semakin tertunda sekitar 3 tahun dari 1970-2010. ${ }^{19}$ Dalam jangka waktu tiga dekade tersebut, jumlah orang yang tidak menikah pada usia 35-39 di tahun 2005 meningkat tiga kali lipat. Angka ini cukup drastis. Berkaca dari meningginya jumlah hingga tiga

\footnotetext{
${ }^{15}$ Ibid., 7.

${ }^{16}$ Ibid.

${ }^{17}$ Ibid., 8.

${ }^{18}$ Seperti dikutip oleh Himawan, Bambling, dan Edirippulige, "The Asian Single Profiles," 8.
}

${ }^{19}$ Himawan, Bambling, dan Edirippulige, "What Does It Mean," 2. 
kali lipat tersebut, T.H. Hull dalam tulisannya memprediksi Indonesia akan menjadi negara dengan tingkat kelajangan tertinggi di Asia dalam tiga dekade mendatang (2010-2040) ${ }^{20}$

Ada beberapa faktor yang menyebabkan angka kelajangan meningkat di Indonesia. Himawan menjelaskan tiga faktor penyebabnya adalah sebagai berikut: ${ }^{21}$ pertama, adanya akses yang seimbang untuk pendidikan dan karier antara perempuan dan pria. Semakin terbukanya jalan bagi perempuan untuk menempuh tingkat pendidikan dan ekonomi yang lebih tinggi di Indonesia menyebabkan mereka memiliki lebih banyak pilihan lain daripada terburu-buru untuk menikah di usia muda. Partisipasi perempuan dalam angkatan kerja telah meningkat tajam, dan pada 2015, hampir $55 \%$ perempuan dipekerjakan (Badan Pusat Statistik, 2016). Hubungan antara tingkat perekonomian dan tingkat kelajangan merupakan sebuah fenomena global, termasuk di Indonesia. Semakin tinggi tingkat ekonomi, semakin tinggi tingkat kelajangan. Sangat dimengerti bahwa seorang perempuan dengan tingkat pendidikan dan posisi karier yang lebih tinggi menetapkan harapan yang lebih tinggi pula untuk pasangan mereka. Menurut survei dari Vignato, banyak wanita menyatakan keengganan mereka untuk menikahi pria berpenghasilan rendah. ${ }^{22} \mathrm{Jadi}$, banyak wanita menjadi lajang bukan karena jumlah pria kurang, yang kurang adalah jumlah pria dengan kriteria yang memenuhi standar perempuanperempuan yang berpenghasilan tinggi.

Kedua, yang menyebabkan meningkatnya tingkat kelajangan di Indonesia adalah tersedianya akses yang lebih mudah untuk pemenuhan kebutuhan emosi dan seks di luar

${ }^{20}$ T.H. Hull, "The Marriage Revolution in Indonesia," makalah dipresentasikan di Population Association of America, Atlanta (May 2002) seperti dikutip oleh Himawan, Bambling, dan Edirippulige, "What Does It Mean," 2.

${ }^{21}$ Himawan, Bambling, dan Edirippulige, "What Does It Mean," 3-4.

${ }^{22}$ Ibid. . pernikahan. ${ }^{23}$ Bagi sebagian masyarakat, pernikahan dan seksualitas tidak lagi dianggap sebagai sebuah proses yang sakral. Meskipun sebagian rakyat masih menganggap tabu seks di luar pernikahan, gaya hubungan yang tidak sehat dengan melakukan seks pranikah jumlahnya meningkat. Dampaknya, status pernikahan yang seharusnya menjadi legalitas dari hubungan seks tidak lagi menjadi urgensi yang harus diperjuangkan. Mereka memilih untuk tetap lajang, toh tetap dapat memenuhi kebutuhan seksual mereka.

Ketiga, yang menyebabkan meningkatnya tingkat kelajangan di Indonesia adalah meningkatnya penggunaan internet. ${ }^{24}$ Penggunaan internet di Indonesia telah tumbuh secara eksponensial, dengan jumlah pengguna meningkat sepuluh kali lipat antara tahun 2004 (11,2 juta) hingga 2017 (143,26 juta). ${ }^{25}$ Penggunaan internet yang sangat besar ternyata membawa dampak signifikan dalam mengurangi kemauan seseorang untuk menikah. Hal ini terjadi karena sifat adiktif pada sosial media dan situs kencan serta penggunaan pornografi yang lebih besar cenderung mengarah kepada isolasi sosial dan mengurangi kemungkinan kemitraan. ${ }^{26}$ Akibat penggunaan internet yang berlebihan, waktu untuk menjalin hubungan yang riil dengan sesama telah tersita. Sayangnya, berkurangnya waktu untuk menjalin hubungan yang lebih berkualitas dengan lawan jenis seakan bukan menjadi masalah besar. Orang-orang muda yang telah kecanduan akan penggunaan internet menjadi asyik dengan dunianya sendiri. Akhirnya, kemungkinan dan keinginan untuk mencari dan menemukan pasangan hidup juga menjadi semakin berkurang.

\footnotetext{
${ }^{23}$ Himawan, Bambling, dan Edirippulige, "What Does It Mean," 3.

${ }^{24}$ Ibid.

${ }^{25}$ Data diambil dari Asosiasi Penyelenggara Jasa Internet Indonesia, Perilaku Pengguna Internet Indonesia 2017 (2018), 7, Adobe PDF.
}

${ }^{26}$ Himawan, Bambling, dan Edirippulige, "What Does It Mean,” 3-4. 


\section{Penyebab Kelajangan di Jemaat Korintus}

Sangat berbeda dengan penyebab kelajangan pada masa kini yang dipengaruhi oleh faktor sosial, ekonomi, dan pendidikan, faktor penyebab yang memengaruhi keputusan untuk melajang di jemaat Korintus adalah karena ajaran yang keliru. Perikop 1 Korintus 7 merupakan tanggapan Paulus atas pengaruh ajaran tertentu yang menimbulkan pandangan kurang tepat di kalangan jemaat soal status perkawinan atau kelajangan mereka. Pasal ini dibuka dengan kalimat, "Dan sekarang tentang hal-hal yang kamu tuliskan kepadaku. Adalah baik bagi laki-laki kalau ia tidak kawin" (7:1). Dari ayat pertama ini, sebagian berpikir bahwa frasa "Adalah baik bagi laki-laki kalau ia tidak kawin" adalah pernyataan Paulus. John Hurd misalnya, berpendapat bahwa ajaran untuk hidup membujang ini memang berasal dari rasul Paulus sendiri ketika ia bekerja selama 18 bulan di Korintus. ${ }^{27}$ Tampaknya, Paulus setuju dengan anggapan bahwa adalah lebih baik bagi seorang pria untuk tidak kawin. Ditambah lagi, keberadaan diri Paulus yang tidak menikah dapat menjadi pengaruh yang membuat jemaat Korintus berpikir bahwa membujang adalah status yang terbaik. Sangat masuk akal bila pilihan pribadi Paulus telah dipakai oleh sebagian jemaat Korintus sebagai pijakan untuk menghindarkan diri dari segala tuntutan nafsu seksual. ${ }^{28}$ Dengan kata lain, status membujang dan tidak melakukan hubungan seksual dianggap sebagai panggilan yang lebih tinggi dan lebih kudus daripada status menikah. ${ }^{29}$

Pandangan di atas kurang tepat karena frasa "adalah baik bagi laki-laki kalau ia tidak kawin" bukan pernyataan Paulus sendiri melainkan pernyataan jemaat Korintus yang Paulus kutip dan kemudian ia tanggapi. Penulis setuju dengan tafsiran David Garland, Anthony

\footnotetext{
${ }^{27}$ John Hurd, The Origin of 1 Corinthians (London: SPCK, 1965), 25

${ }^{28}$ Tridarmanto, "Menikah? Baik. Tidak? Lebih Baik," 17.

${ }^{29}$ Anthony C. Thiselton, The First Epistle to the Corinthians, The New International Greek Testament Commentary (Grand Rapids: W.B. Eerdmans, 2000), 495.
}

Thiselton, Leon Morris, dan Craig Blomberg bahwa slogan untuk tidak kawin tersebut sangat lebih tepat ditafsir sebagai kutipan Paulus dari pikiran jemaat Korintus yang menyuratinya. Tulisan Paulus dalam pasal ini merupakan reaksi terhadap surat yang ditulis oleh jemaat Korintus kepadanya soal menikah dan selibat. Thiselton menyatakan beberapa argumen yang cukup meyakinkan untuk pandangan ini: ${ }^{30}$ pertama, ada kesamaan struktural antara kutipan 7:1 dengan kutipan Paulus dari jemaat Korintus pada bagian lain, yaitu di 8:1, 8:8, dan 8:5-6; kedua, pandangan ini bukan tafsiran baru melainkan argumen para sarjana zaman kuno seperti Origen, yang dengan tegas menyatakan bahwa slogan itu mencerminkan kebingungan atau perpecahan ( $\dot{\alpha} \kappa \alpha \tau \alpha \sigma \tau \alpha \sigma i ́ \alpha)$ di gereja Korintus yang diprakarsai oleh orang-orang yang berpendapat bahwa abstinensi asketis adalah "hal yang baik"; dan ketiga, bila Paulus setuju seorang pria lebih baik tidak menikah, hal ini tidak sejalan dengan konsep di Kejadian 2:18 bahwa "tidak baik kalau manusia itu seorang diri saja."

Penafsiran kata "kawin" dalam frasa tersebut menjadi perdebatan di antara para sarjana penafsir. Ada dua penafsiran yang mengartikan kata "kawin" dalam bagian tersebut. Pertama, kawin diartikan sama dengan menikah. Sebagian terjemahan bahasa Inggris seperti NIV dan TEV menerjemahkan frasa tersebut dengan "it is good for a man not to marry." Tafsiran kedua untuk ungkapan "tidak kawin" yang berasal dari bahasa Yunani

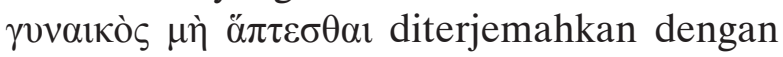
"tidak menjamah perempuan." Terjemahanterjemahan yang mengikuti tafsiran kedua ini adalah versi KJV dan RSV menerjemahkan bagian ini dengan "not to touch a woman." Beberapa penafsir seperti Fee, Garland, dan Morris mengatakan bahwa arti kawin dalam ayat ini berbicara soal hubungan seksual antara pria dan wanita.

Penulis sependapat dengan tafsiran kedua. Tafsiran kedua ini juga diikuti oleh para sarjana yang belakangan ini melakukan

${ }^{30}$ Ibid., 493. 
eksegesis khusus 1 Korintus 7, misalnya Ikechi C. Ekpendu, Katy E. Valentine, Davidson Razafiarivony, Roy E. Ciampa. ${ }^{31}$ Ada beberapa alasan yang memperkuat tafsiran kata "kawin" dalam ayat 1 sebagai hubungan seksual. Pertama, beberapa literatur yang berpengaruh kuat terhadap budaya Yunani-Romawi menunjukkan bahwa idiom touch a woman dalam ayat 1 digunakan dan dikenal sebagai eufemisme untuk memperhalus ungkapan berhubungan seksual. Menurut Fee dan Ciampa, hingga saat ini bentuk eufemisme tersebut ditemukan dalam teks-teks kuno untuk menunjukkan aktivitas hubungan seksual. Fee menunjukkan tujuh teks kuno seperti tulisan Plato berjudul Leges, tulisan Aristoteles berjudul Politica, Kejadian 20:6, Amsal 6:29, tulisan Plutarch berjudul Alexander, tulisan Josephus, dan tulisan Marcus Aurelius, semuanya memakai idiom "menjamah perempuan" dengan arti berhubungan seksual. ${ }^{32}$ Daftar teks-teks kuno yang menunjukkan arti idiom tersebut diperpanjang oleh Ciampa. Dalam tulisannya "Revisiting the Euphemism in 1 Corinthians," dengan lebih lengkap Ciampa mengutip dan menunjukkan 25 teks kuno seperti tulisan Plato, tulisan-tulisan Aristoteles, kitab Kejadian, kitab Ruth, kitab Amsal, tulisan-tulisan Josephus, tulisantulisan Plutarch, Testament of Reuben, dan tulisan Marcus Aurelius yang menunjukkan bahwa penggunaan idiom 'menjamah' dalam konteks budaya Yunani-Romawi pada waktu itu merupakan eufemisme atau bentuk halus dari aktivitas berhubungan seksual. ${ }^{33}$

${ }^{31}$ Lih. Ikechi Chidi Ekpendu, "Celibacy: An Exegetical Study of 1 Cor. 7:1" International Journal of Research in Humanities and Social Studies 3 no. 9 (september 2016): 30, Katy E. Valentine, "1 Corinthians 7 in Light of Ancient Rhetoric of Self-Control" Review and Expositor 10 (2013): 578-579, Davidson Razafiarivony, "Marriage and Sexual Obligations according to Paul in 1 Corinthians 7:1-7" IOSR Journal of Humanities and Social Science 22 No. 8 (Agustus 2017): 66, dan Roy E. Ciampa, "Revisiting the Euphemism in 1 Corinthians 7.1" Journal for the Study of the New Testament 31 No. 3 (2009): 326.

${ }^{32}$ Gordon Fee, "1 Corinthians 7:1 in the NIV" Journal Of The Evangelical Theological Society 23 no. 4 (Desember 1980): 307-308).

${ }^{33}$ Ciampa, "Revisiting the Euphemism in 1 Corinthians 7.1, 326-335.
Dalam tulisannya yang berjudul 1 Corinthians 7 in Light of Ancient Rhetoric of Self-Control, Valentine memperkuat tafsiran ini dengan mengatakan bahwa hasrat seksual yang tidak terkontrol merupakan kecemasan masyarakat secara umum saat itu. ${ }^{34}$

Kedua, pemaknaan kata 'menjamah' sebagai hubungan seksual dalam 1 Korintus 7:1 sangat sesuai dengan konteks pasal 6-7. Kata 'kawin' dalam 1 Korintus 7:1 diapit dengan teguran Paulus di bagian sebelum dan sesudahnya tentang dosa percabulan. Pada 1 Korintus 6:12-20, Paulus menegur soal dosa percabulan, kemudian Paulus melanjutkan nasihatnya soal hawa nafsu seksual di pasal 7:2-4. ${ }^{35}$ Melalui konteks ini, sangat masuk akal bila makna yang lebih tepat untuk kata 'kawin' pada 7:1 bukan hanya soal menikah, melainkan lebih spesifik, yaitu hubungan seksual.

Ada tendensi dalam diri jemaat Korintus untuk memilih selibat daripada menikah. Pertanyaan yang muncul dari bagian ini adalah: dari manakah asalnya tendensi untuk hidup selibat itu muncul? Penulis sependapat dengan Fee yang mengatakan bahwa pengaruh kuat yang merasuki pandangan jemaat Korintus saat itu bukan hanya teologi eskatologi baru, melainkan juga paham dualistik Yudaisme-Hellenistik. ${ }^{36}$ Paham ini sangat memisahkan antara jasmani (tubuh) dan rohani (jiwa). Hal ini membuat jemaat memiliki konsep yang buruk terhadap tubuh. Tidak heran pula di pasal 15, Paulus menekankan soal kebangkitan tubuh yang menjadi tanggapan penting untuk menghadapi paham yang keliru tersebut. ${ }^{37}$ Konsep mereka yang rendah akan tubuh menyebabkan mereka enggan untuk menikah. Garland menambahkan bahwa pandangan dualisme yang ada dalam diri jemaat Korintus membuat mereka memandang tubuh yang melakukan hubungan seksual

\footnotetext{
${ }^{34}$ Valentine, "1 Corinthians 7," 580.

${ }^{35}$ Ekpendu, “Celibacy: An Exegetical,” 30-31.

${ }^{36} \mathrm{Fee}$, “1 Corinthians 7:1,” 313.

${ }^{37}$ Fee, "1 Corinthians 7:1,” 313.
} 
menodai sifat spiritual seseorang. ${ }^{38}$ Dengan konsep dualisme yang merasuki pikiran jemaat Korintus, aturan hidup bertarak secara seksual ini telah menjadi prinsip religius masyarakat yang tidak begitu saja ditinggalkan oleh jemaat sekalipun mereka telah percaya kepada Kristus.

Paham dualisme yang merasuki pikiran jemaat Korintus seperti ini bukanlah perkara yang baru dalam dunia keagamaan. Richard A. Horsley mengatakan bahwa motif yang sama ditemukan pula di dalam konsep YudaismeHellenistik, khususnya terdapat dalam konsep tentang "spiritual marriage." 39 Menikah dengan Juruselamat secara rohani yang menuntut pola hidup bertarak seksual seperti ini dapat ditemukan di dalam tulisan-tulisan kitab Kebijaksanaan Salomo dan Philo. Horsley menemukan banyak kesamaan baik dalam hal konsep maupun bahasa antara tulisan-tulisan ini dengan surat 1 Korintus. Bertarak dari aktivitas seksual adalah cara mereka untuk keluar dari dunia dan menuju kepada Tuhan. Semboyan "lebih baik tidak kawin" ini berasal dari perspektif jemaat yang menganggap hubungan seks sebagai dosa. Dengan paham tersebut, mereka berpikir bahwa melajang adalah status yang lebih kudus daripada menikah.

\section{PETUNJUK-PETUNJUK PAULUS SOAL SELIBAT DARI 1 KORINTUS 7}

Menanggapi pergumulan jemaat Korintus, Paulus menyatakan tanggapannya. Berdasarkan studi eksposisional dari 1 Korintus 7, penulis akan memaparkan dua hal: pertama, alasan untuk memutuskan hidup selibat atau menikah bukan soal mana yang lebih kudus melainkan harus didasarkan pada karunia; kedua, ada beberapa petunjuk yang dapat ditemukan dari nasihat Paulus untuk memutuskan hidup selibat, yaitu soal perhatian hidup, dorongan seksualitas, dan keyakinan hati.

\footnotetext{
${ }^{38}$ David E. Garland, 1 Corinthians, Baker Exegetical Commentary on the New Testament (Grand Rapids: Baker, 2003), 356.

${ }^{39}$ Richard A. Horsley, "Spiritual Marriage With Sophia," Virgiliae Christianae 33, no. 1 (1979), 46-54.
}

\section{Karunia untuk Selibat}

Keputusan untuk menikah atau selibat seharusnya didasarkan pada sebuah alasan yang tepat, yaitu karunia. Hal ini tidak dipahami oleh jemaat Korintus, pertimbangan mereka untuk menikah atau selibat dipengaruhi oleh asketisme. Paulus tidak setuju bila orang ingin selibat dengan alasan bahwa seks itu dosa. Secara implisit, Paulus menolak paham asketisme, hal ini terlihat dari tulisannya dari ayat 2-5. Paulus dengan tegas tidak menyetujui bahwa seks di dalam pernikahan adalah dosa, sebaliknya bagi Paulus seks di dalam pernikahan adalah kudus. Hal ini terbukti dengan nasihatnya yang justru membujuk jemaat suami istri untuk melakukan kewajibannya masing-masing soal persetubuhan (ay. 3-5). Paulus bahkan dengan jelas berkata, "Jangan kamu saling menjauhi” (ay. 5). Dengan paham asketis, ada indikasi bahwa di antara jemaat yang sudah menikah ingin menghindari seksualitas dan bahkan berniat berpisah atau bercerai dengan alasan supaya kudus. ${ }^{40}$ Paulus menasihatkan hal yang sebaliknya. Ia berkata bahwa orang yang menikah perlu melakukan aktivitas seksualitasnya dalam rangka memenuhi kebutuhan pasangan di dalam ikatan pernikahan.

Paulus menyetujui seseorang memutuskan untuk selibat dengan satu alasan, yaitu bila diberi karunia $(\chi \alpha ́ \rho \imath \sigma \mu \alpha)$ untuk selibat. Paulus beberapa kali mendorong jemaat untuk "turuti teladanku." Dalam pasal 7 ini ia juga mengatakan hal senada, "namun alangkah baiknya kalau semua orang seperti aku." Secara pribadi, Paulus menghendaki agar jemaat di Korintus hidup tidak menikah seperti dirinya, namun dalam kalimat yang sama Paulus segera melanjutkan, "tetapi setiap orang menerima dari Allah karunianya yang khas, yang seorang karunia ini, yang lain karunia itu."41 Sesuai dengan konteksnya, "seperti aku" merujuk pada gaya hidup selibat yang dianut oleh Paulus. Paulus mengatakan bahwa tidak menikah adalah suatu hal yang baik, namun walaupun demikian ia menyadari menjadi

\footnotetext{
${ }^{40}$ Thiselton, The First Epistle to the Corinthians, 493

${ }^{41}$ Penekanan oleh penulis.
} 
selibat bukan keharusan bagi semua orang karena tidak semua orang dikarunia hal itu. Mereka yang mendapat karunia yang lain, yakni "karunia itu" yang dalam konteks ini yang dimaksud tentu saja menikah, Paulus menasihatkan bahwa mereka harus meneruskan pernikahannya, bahkan mempertahankan pernikahannya (ay. 10).

Yang Paulus soroti soal seksualitas yang berdosa adalah bukan di dalam pernikahan, me-

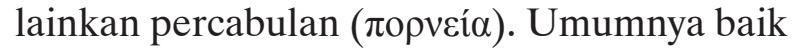
bagi kaum Yahudi maupun bukan Yahudi, is-

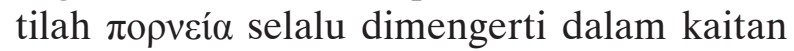
dengan tindakan melakukan hubungan seksual oleh bukan pasangan suami istri. Di ayat 2 Paulus mengingatkan soal bahaya percabulan. Di ayat 9, Paulus menyinggung hal yang sama, yaitu soal terjerumus oleh hawa nafsu, dalam konteks ini jelas adalah nafsu seksual. Paulus mengatakan kepada jemaat bahwa mereka

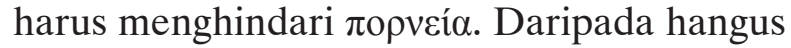
oleh hawa nafsu dan jatuh pada percabulan, jemaat yang tidak memiliki karunia selibat seharusnya menikah.

Namun, pertanyaan lebih lanjut yang dapat muncul dari bagian ini adalah apakah Paulus memandang selibat sebagai panggilan yang baik dan lebih kudus daripada menikah. Menanggapi pertanyaan ini, pertama, perlu dilihat dari konteks jemaat di Korintus bahwa mereka justru sedang bergulat dengan pengaruh asketisme, yang memandang selibat lebih kudus dari pada menikah. Paulus menanggapi pengaruh tersebut dan justru ingin menjelaskan bahwa paham tersebut tidak benar. ${ }^{42}$ Paulus ingin menyeimbangkan konsep bahwa menikah atau selibat, dua-duanya kudus, asal sejalan dengan karunianya masing-masing. Berulang kali dalam pasal 7 ini, Paulus mengatakan bahwa menikah itu tidak berdosa (ay. 28, 36, 38), artinya Paulus memandang bahwa menikah adalah sebuah hal yang kudus.

Kedua, Thiselton sempat menerangkan bahwa masalah ini perlu ditempatkan dalam kerangka desakan Paulus bagi jemaat di Korintus

\footnotetext{
${ }^{42}$ Stephen Vantassel, "Celibacy: The Forgotten Gift of the Holy Spirit," The Journal of Biblical Counseling 12 no. 3 (1994): 20.
}

bahwa semua orang Kristen adalah satu, dan setiap karunia sama-sama penting dan diperlukan untuk gereja (1Kor. 12: 12-31). Penulis setuju dengan Stephen Vantassel dalam tulisannya soal karunia selibat yang mengatakan semua karunia sama pentingnya dalam kesatuan tubuh Kristus, walaupun tidak semua karunia sama dalam hal manfaatnya. ${ }^{43}$ Memang, karunia selibat memiliki beberapa manfaat yang tidak dimiliki oleh orang yang menikah (ay. 34-35). Namun, semua karunia termasuk selibat atau menikah memiliki bagian dan peran dalam kesatuan tubuh Kristus. ${ }^{44}$ Oleh karena itu, tidak sepantasnya sebuah karunia dipandang lebih rendah dari karunia yang lain.

\section{Perhatian Hidup bagi Tuhan}

Bagaimana mengenali karunia untuk hidup selibat? Mengenai pertimbangan untuk hidup selibat, Paulus secara lebih jelas memberikan nasihatnya di ayat 25-38. Setelah berbicara kepada jemaat Korintus secara umum soal pernikahan dan hidup sendiri, secara spesifik mulai ayat 25 ia berbicara tentang "para gadis.” LAI menerjemahkan kata $\pi \alpha \rho \theta \varepsilon ́ v o \varsigma$ di ayat 25 dengan "para gadis," yang sama dengan beberapa terjemahan bahasa Inggris, yaitu virgins. Garland lebih lanjut menerangkan bahwa virgins yang dimaksud tidak terbatas pada wanita melainkan mereka yang belum menikah, baik laki-laki maupun perempuan. ${ }^{45}$ ESV menerjemahkan kata $\pi \alpha \rho \theta \varepsilon ́ v o \varsigma$ dengan "mereka yang bertunangan." Terjemahan ini disetujui oleh sebagian penafsir, misalnya Gordon Fee, Garland, dan Thiselton. Bagian ini secara lebih spesifik ditujukan kepada mereka yang telah bertunangan namun belum menikah dan terpengaruh dengan ajaran

\footnotetext{
${ }^{43}$ Vantassel, “Celibacy,” 20.

${ }^{44}$ Ibid., 21.

${ }^{45}$ Kata parthenos memang bersifat feminim, namun Garland menjelaskan bahwa penggunaan kata ini dapat ditujukan kepada laki-laki (Mis. Wahyu 14:4), lihat Garland, 1 Corinthians, 358. Beberapa penafsir lain juga sepandapat bahwa parthenos dapat ditujukan kepada pria, lih. Thiselton, The First Epistle to the Corinthians, 570, dan Gordon D. Fee, The First Epistle to the Corinthians, The New International Commentary on the New Testament (Grand Rapids: Eerdmans, 1987), 322.
} 
asketisme yang mengatakan "lebih baik bagi pria bila tidak kawin." 46 Ada indikasi bahwa mereka yang telah bertunangan pun menjadi ragu untuk menikah karena berpikir bahwa menikah dan seks lebih buruk daripada selibat.

Bagi mereka yang sedang bergumul untuk menikah atau selibat, Paulus memberikan dua pilihan bagi mereka. Bila mereka mau menikah, Paulus berulang kali menekankan bahwa mereka tidak berdosa (ay. 28, 36, 38). Namun, bila mereka ingin selibat, salah satu hal yang perlu diperhatikan adalah fokus hidup untuk melayani Tuhan (ay. 32-35). Bagi jemaat Korintus yang sudah bertunangan, mereka dapat memilih untuk menjadi selibat bila mereka ingin memusatkan pikiran untuk melayani Tuhan. Kata "kekuatiran" pada ayat 32 dengan "memusatkan perhatian" berasal dari akar kata yang sama dalam bahasa Yunani, yaitu $\mu \varepsilon \rho \mu v \tilde{\alpha} .{ }^{47}$ Memusatkan perhatian atau khawatir berarti fokus atau mencurahkan pikiran pada satu hal di mana pun dan kapan pun. Paulus mengatakan bahwa orang yang menikah memusatkan pikiran pada perkara duniawi (ay. 33), secara khusus mereka memusatkan perhatian untuk pasangan dan keluarga. Sebaliknya, orang yang selibat memiliki kebebasan yang lebih untuk memusatkan perhatian pada perkara-perkara yang ditujukan untuk pekerjaan Tuhan. Bila ingin melayani Tuhan tanpa terbagi, orang yang telah bertunangan dalam jemaat Korintus ini boleh untuk tidak menikah. Paulus mengatakan di ayat 34 bahwa perempuan yang tak bersuami dan para gadis memusatkan pikiran pada perkara Tuhan supaya jiwa dan tubuhnya kudus. Kalimat Paulus tersebut bukan sedang mengartikan bahwa seks itu kotor dan tidak kudus, seperti pandangan asketisme. Kata kudus di sini lebih tepat dipisahkan atau dikhususkan secara utuh dan eksklusif, artinya seluruh tubuh (material) dan rohnya (nonmaterial) diabdikan secara total bagi Tuhan dan tidak ada hal yang membuatnya terbagi, tidak ada hal

${ }^{46} \mathrm{Fee}$, The First Epistle to the Corinthians, 332.

${ }^{47}$ Thiselton, The First Epistle to the Corinthians, 586. yang menjadi gangguan dalam hidupnya (ay. $35) .{ }^{48}$

Ketika Paulus mengatakan bahwa orang yang selibat memiliki fokus untuk Tuhan, tidak berarti ia sedang memandang pernikahan adalah hal yang lebih buruk, pernikahan memiliki keindahan yang lain. ${ }^{49}$ Namun, dalam bagian ini Paulus sedang mengajak pembacanya untuk melihat keindahan hidup yang dimiliki oleh orang yang diberi karunia selibat. Seperti Paulus, ia lebih bebas untuk melayani Tuhan karena tidak ada tanggung jawab keluarga yang mengikat. Pria atau wanita yang telah menikah akan membagi perhatiannya yaitu untuk Tuhan dan pasangannya. ${ }^{50}$ Paulus mengatakan hal ini bukan memaksa, tetapi demi kepentingan jemaat Korintus sendiri (ay. 35). Kata kepentingan di sini berarti demi keuntungan. ${ }^{51}$ Dengan kata lain, bila orang memutuskan untuk selibat, mereka akan memiliki banyak keuntungan untuk melayani jemaat Tuhan.

Ada beberapa tokoh Alkitab yang memiliki fokus dengan sangat kuat untuk menyerahkan sepenuh waktunya demi melayani Tuhan tanpa terbagi. Mereka adalah pelayan Allah yang diberi karunia untuk selibat. Beberapa contoh tokoh yang dimaksud adalah Yeremia, Yohanes Pembaptis, Paulus, dan Yesus

${ }^{48}$ Roy E. Ciampa dan Brian S. Rosner, The First Letter to the Corinthians, Pillar New Testament Commentary (Grand Rapids: William B. Eerdmans, 2010), 353.

\footnotetext{
${ }^{49}$ Salah satu keindahan dari pernikahan adalah pernikahan merupakan wadah orang percaya mengalami dan mempraktikkan kasih Allah. Bagi orang yang tidak diberi karunia selibat, keberadaan dan kasih dari suami atau istri menjadi sebuah kebutuhan. Dalam kitab Hosea, kasih suami kepada istri dipakai oleh Allah untuk mengilustrasikan kasih-Nya kepada umat-Nya. Kasih yang dimaksud di sini berbicara soal pengampunan, penerimaan kembali, pengorbanan, pemberian hati dan diri. Paulus sendiri dalam kitab Efesus juga mengatakan bahwa suami harus mengasihi istri seperti Kristus mengasihi jemaat (Ef. 5:25). Dalam pernikahan, kasih Allah dialami sekaligus dipraktikkan secara kuat, hebat, dan intensif baik itu soal pengampunan, penerimaan kembali, pengorbanan, pemberian hati dan diri. Hal ini merupakan keindahan pernikahan yang tidak dialami oleh orang yang hidup selibat.
}

${ }^{50}$ Thiselton, The First Epistle to the Corinthians, 567.

${ }^{51}$ Fee, The First Epistle to the Corinthians, 347. 
sendiri. Dalam Matius 19:12, Yesus berkata, "Ada orang yang tidak dapat kawin karena ia memang lahir demikian dari rahim ibunya, dan ada orang yang dijadikan demikian oleh orang lain, dan ada orang yang membuat dirinya demikian karena kemauannya sendiri oleh karena Kerajaan Sorga. Siapa yang dapat mengerti hendaklah ia mengerti." Alasan terakhir dari perkataan Yesus mengenai orang yang tidak menikah adalah karena mereka mau membuat dirinya demikian (menjadi selibat) demi Kerajaan Surga. Mereka diberi karunia selibat dan memiliki banyak keuntungan dalam melayani Allah. Alasan di balik kehidupan selibat yang mereka jalani tentunya tidak bersifat kultural. ${ }^{52}$ Dalam gaya hidup Yudaisme, budaya patriarkal (berpusat pada laki-laki) sangat dominan. Kelanjutan sebuah keturunan melalui pernikahan merupakan sebuah kehormatan dan menguntungkan karena berhubungan soal warisan tanah. Kehidupan selibat yang dipilih oleh Tuhan Yesus, Yohanes Pembaptis, dan Paulus justru tidak sesuai arus budaya. Namun, mereka memilih demikian karena memiliki karunia untuk selibat dan demi kepentingan pekerjaan Allah.

\section{Dorongan Seksualitas}

Hal kedua yang Paulus tunjukkan melalui 1 Korintus 7 soal keputusan selibat dapat dipertimbangkan dari dorongan seksualitas. Tentunya setiap orang memiliki dorongan atau nafsu seksualitas. Namun, ada sebagian orang yang memiliki dorongan seksual yang tinggi sehingga sulit untuk dikendalikan. Bila kebutuhan akan dorongan tersebut tidak dipenuhi, masalah dapat timbul dengan hebatnya. Bagi orang seperti ini, Paulus menasihatkan untuk menikah saja (ay. 9). Sebaliknya, ada sebagian orang lain yang dapat memegang kendali atau menguasai hasratnya dengan baik. Bagi orang seperti ini, Paulus mengatakan bahwa mereka dapat memutuskan untuk selibat. Di ayat 37 Paulus mengatakan, "Tetapi jikalau ia menyangka, bahwa ia berlaku tidak wajar

\footnotetext{
${ }^{52}$ Norman A. Huffman, "Did Jesus or Paul Marry?" Journal of Ecumenical Studies 5 no. 4 (1968), 742.
}

kepada terhadap gadisnya, jika gadisnya itu bertambah tua, ia benar-benar merasa bahwa mereka harus kawin, baiklah mereka kawin, kalau ia menghendakinya." Hal yang perlu diperjelas dari bagian pertama ayat tersebut adalah frasa "berlaku tidak wajar." Fee menjelaskan bahwa frasa tersebut merujuk soal kondisi tidak baik karena mereka (jemaat Korintus yang sedang dinasihati oleh Paulus) telah bertunangan namun tidak kunjung menikah. ${ }^{53}$ Kondisi tersebut kemungkinan besar dikarenakan mereka bergulat dalam batin antara dua pilihan, yaitu untuk menikah atau selibat.

Paulus melanjutkan kalimatnya dengan

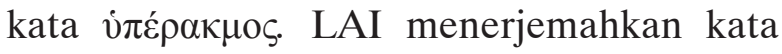

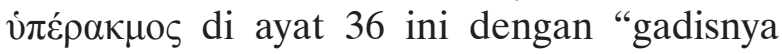
bertambah tua" artinya subjek dari kata sifat tersebut adalah gadis. Fee menerangkan bahwa sebenarnya subjek dari kata sifat tersebut tidak terbatas pada gadis, namun juga dapat dikenakan pria. ${ }^{54}$ Suku kata vi $\pi \rho$ dari kata ini juga dapat diterjemahkan dengan melampaui. ${ }^{55}$ Dalam bagian ini, terjemahan LAI telah menafsirkan sesuatu yang bertambah tersebut adalah umur, terjemahan yang diberikan adalah "bertambah tua." Menurut Fee, kata tersebut dapat diartikan bertambah dalam nuansa yang lain, yaitu soal bertambah gairah atau bertambah sesuatu secara seksual. ${ }^{56}$ Tafsiran ini juga didukung oleh Will Deming. Ia mengatakan bahwa melalui ayat 36 ini, terlihat lebih jelas bahwa bagi Paulus, selibat bukan keharusan absolut yang menjadi kondisi terbaik bagi sebagian orang, khususnya bagi mereka yang memiliki dorongan seksualitas yang kuat. ${ }^{57}$ Bruce W. Winter yang membuat tulisan khusus soal terjemahan kata ini menerangkan bahwa bila dilihat dari tata bahasa dan gramatika dari kalimat

${ }^{53} \mathrm{Fee}$, The First Epistle to the Corinthians, 350.

${ }^{54}$ Ibid.

${ }^{55}$ Ibid.

${ }^{56}$ Ibid.

${ }^{57}$ Will Deming, Paul on Marriage and Celibacy: The Hellenistic Background of 1 Corinthians 7 (Grand Rapids: William B. Eerdmans, 2004), 215. 
tersebut, terjemahan yang paling tepat untuk

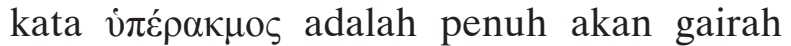
seksual. ${ }^{58}$ Jika pria yang sudah bertunangan tersebut memiliki dorongan seksual yang berlebihan, maka Paulus menasihatkan untuk menikah. Terlihat melalui bagian ini, Paulus sangat realistis soal kehidupan seksualitas seseorang. Bagi sebagian orang tersebut, menikah merupakan status yang lebih baik (ay. 38) karena di dalam pernikahan, kebutuhan seseorang soal seksualitasnya dapat terpenuhi.

Paulus melanjutkan nasihatnya di ayat 37 bahwa bila seseorang memiliki keputusan untuk tidak akan menikah, hal itu juga baik. Bila seorang jemaat Korintus pria yang sudah bertunangan memutuskan untuk tidak menikahi gadisnya, Paulus mengatakan bahwa salah satu kondisi yang mendukung keputusan itu adalah bila ia benar-benar menguasai kemauannya. Kata "menguasai" dalam kalimat tersebut secara literal dapat diterjemahkan dengan memegang kendali atau memiliki otoritas. ${ }^{59}$ Sedangkan kata "kemauan" (terjemahan lain adalah kehendak) yang Paulus maksud menurut Winter bukan berbicara soal kehendak untuk menikah. Menurutnya, terkait dengan

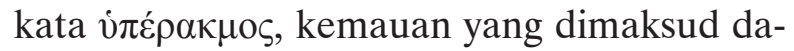
lam ayat 37 adalah kemauan seksual. ${ }^{60}$ Paulus mengatakan bahwa bila seseorang dapat menguasai atau punya otoritas atau memegang kendali soal hasrat seksualitasnya, ia dapat memutuskan untuk selibat. Dengan kata lain, bagi orang yang Paulus bicarakan tersebut, nafsu seks bukan menjadi masalah besar yang akan menjerumuskannya.

Dorongan seksual merupakan salah satu faktor penting untuk memutuskan seseorang akan menikah atau tidak. Di bagian sebelumnya, yaitu 7:2, Paulus menasihatkan bahwa karena mengingat bahaya percabulan, lebih baik seseorang untuk kawin. Pada 7:9, Paulus berkata lebih baik kawin daripada hangus karena

\footnotetext{
${ }^{58}$ Bruce W. Winter, "Puberty or Passion? The Referent of $v \pi \varepsilon \rho \alpha \kappa \mu о \sigma$ in 1 Corinthians 7:36," Tyndale Bulletin 49 no. 1 (1998), 87.

${ }^{59}$ Ciampa dan Rosner, The First Letter to the Corinthians, 360.

${ }^{60}$ Winter, "Puberty or Passion," 85.
}

hawa nafsu. Dari bagian ini, apakah dapat dikatakan bahwa orang yang memiliki dorongan seksual yang tinggi berarti tidak memiliki karunia selibat? Paulus tidak mengatakan secara langsung demikian. Namun, kesimpulan yang dapat ditarik dari nasihat Paulus bagi orang yang berkebutuhan tinggi akan seksualitas sebaiknya menikah menyiratkan bahwa orang-orang demikian tidak tepat untuk selibat. Selibat hanya akan membuat mereka terjerat dengan persoalan-persoalan hawa nafsu (7:9). Orang yang sulit untuk mengontrol dorongan seksualnya, ia diberi karunia untuk menikah. Sedangkan bila hawa nafsu bukan menjadi masalah besar untuk dirinya, orang seperti ini dapat memutuskan untuk tidak menikah.

\section{Keyakinan Hati}

Petunjuk ketiga untuk seseorang memutuskan menjadi selibat adalah soal keyakinan dalam hati. Paulus berkata di ayat 37, "Tetapi kalau ada seorang, yang tidak dipaksa untuk berbuat demikian, benar-benar yakin dalam hatinya dan benar-benar menguasai kemauannya, telah mengambil keputusan untuk tidak kawin dengan gadisnya, ia berbuat baik." Pada bagian pertama ayat ini, Paulus menyoroti soal keputusan yang tidak berdasarkan pada paksaan orang lain. Walaupun tercemar dengan ajaran asketis yang mementingkan selibasi, orang yang telah bertunangan pada masa jemaat Korintus saat itu tetap memiliki tekanan eksternal untuk menikah. ${ }^{61}$ Di tengah kondisi tersebut, Paulus memberikan sebuah nasihat supaya keputusan mereka untuk menikah atau selibat tidak dipengaruhi oleh orang lain. Menurut Paulus, keputusan untuk selibat harus berasal dari keyakinan dalam hati. Dalam bahasa Yunani, frasa "benar-benar yakin dalam hatinya" dapat diterjemahkan dengan "diteguhkan di dalam hatinya dengan kuat." Kata hati yang berasal dari bahasa Yunani $\kappa \alpha \rho \delta i ́ \alpha$ dalam ayat tersebut memiliki arti yang dalam karena berbicara soal pusat kehidupan. Menurut Thiselton, keyakinan dalam hati yang dimaksud oleh Paulus memiliki empat aspek, yaitu soal keyakinan intelektual,

${ }^{61}$ Thiselton, The First Epistle to the Corinthians, 622-623. 
kedalaman emosi, komitmen yang berkehendak, dan pendirian total. ${ }^{62}$

Keputusan yang diambil untuk selibat oleh seseorang perlu didasarkan pada sebuah kemantapan dan pendirian yang penuh, bukan diwarnai oleh keraguan atau hanya berdasarkan pada perasaan dan kondisi sesaat. Seseorang yang telah mengambil keputusan untuk selibat merupakan orang yang telah sangat yakin dan teguh di dalam batinnya bahwa keputusan tersebut adalah yang terbaik bagi dirinya. Ia juga akan terus berkomitmen dan memiliki pendirian total untuk menghidupi keputusannya tanpa digoyangkan oleh keadaan sekitar yang memengaruhi atau membujuknya kepada status hidup yang lain. Ragu-ragu mungkin adalah sebuah kondisi hati yang dapat mewarnai orang muda yang akan hidup selibat, namun bila mereka diberi karunia selibat maka dalam proses berjalannya waktu, mereka akan dimantapkan dan diteguhkan sehingga pada saat keputusan diambil, hal tersebut bukan menjadi sebuah paksaan dan penyesalan melainkan sebuah keyakinan yang mendatangkan sukacita.

Dari uraian di atas dapat disimpulkan bahwa keputusan untuk menikah atau selibat harus didasarkan pada karunia. Karunia tersebut harus dikenali oleh seseorang dalam masa pergumulan mereka menentukan status hidup. Bagi seseorang yang sedang menggumulkan untuk selibat, Paulus memberikan tiga petunjuk yang dapat kita pelajari, yaitu berkaitan dengan fokus hidup untuk melayani Tuhan, dorongan seksualitas, dan keyakinan hati.

\section{IMPLIKASI PRAKTIS BAGI GEREJA MASA KINI}

Berikut ini akan dijelaskan secara singkat implikasi praktis berupa tiga peran yang dapat dilakukan oleh gereja masa kini untuk menolong jemaat, khususnya pemuda-pemudi yang sedang bergumul untuk menentukan status hidup mereka, yaitu pertama, gereja perlu menolong anak-anak muda mengenali karunia

\footnotetext{
${ }^{62}$ Thiselton, The First Epistle to the Corinthians, 599.
}

mereka dengan memberikan pemahaman alkitabiah yang berkaitan dengan topik selibat. Saat hari Valentine diperingati oleh dunia, tak jarang gereja mengkhotbahkan soal tema kasih, pernikahan, dan LSD (Love, Sex, and Dating). Namun, tema selibat agaknya lebih jarang, bahkan sangat sedikit disinggung oleh gereja. Pengajaran tentang topik selibat dapat diberikan oleh gereja melalui khotbah, seminar, pemahaman Alkitab (PA), atau diskusi dalam kelompok pemuridan. Kedua, yang dibutuhkan oleh mereka yang akan menikah atau selibat adalah persahabatan. Oleh karena itu, gereja perlu mewadahi jemaat mudanya memiliki komunitas Kristen yang sehat. Bagi jemaat yang berkarunia menikah, komunitas akan membantu anak-anak muda mencari dan menemukan pasangan hidup yang seiman. Sedangkan bagi mereka yang akan selibat, mereka membutuhkan komunitas supaya menemukan sahabat untuk mereka berbagi hidup. Seorang selibat yang memiliki relasi yang akrab, baik itu dengan keluarga asal, rekan, kolega, atau teman gereja, akan memiliki kualitas hidup yang lebih baik. Ketiga, gereja dapat memberi kepercayaan pelayanan yang lebih kepada jemaat yang selibat. Seorang yang selibat umumnya tidak memiliki tanggung jawab keluarga yang mengikat seperti orang yang menikah. Mereka memiliki lebih banyak waktu dan kebebasan untuk melayani Tuhan sehingga gereja dapat memperlengkapi mereka yang selibat untuk memusatkan perhatian bagi pelayanan pekerjaan Tuhan.

\section{DAFTAR KEPUSTAKAAN}

Asosiasi Penyelenggara Jasa Internet Indonesia, Perilaku Pengguna Internet Indonesia 2017. 2018. Adobe PDF.

Ciampa, Roy E. "Revisiting the Euphemism in 1 Corinthians 7.1," Journal for the Study of the New Testament 31, No. 3 (2009): 325-338.

Ciampa, Roy E. dan Rosner, Brian S. The First Letter to the Corinthians, Pillar New Testament Commentary. Grand Rapids: William B. Eerdmans, 2010. 
Deming, Will. Paul on Marriage and Celibacy: The Hellenistic Background of 1 Corinthians 7. Grand Rapids: William B. Eerdmans, 2004.

Ekpendu, Ikechi Chidi. "Celibacy: An Exegetical Study of 1 Cor. 7:1," International Journal of Research in Humanities and Social Studies 3, no. 9 (September 2016): 29-33.

Febriana, Mariani. "Lajang dalam Gereja dan Pelayanan," Jurnal Theologi Aletheia 17, No.8 (Maret 2015): 29-48.

Fee, Gordon D. "1 Corinthians 7:1 in the NIV," Journal of The Evangelical Theological Society 23, no. 4 (Desember 1980): 307-314.

. The First Epistle to the Corinthians. The New International Commentary on the New Testament. Grand Rapids: Eerdmans, 1987.

Garland, David E. 1 Corinthians. Baker Exegetical Commentary on the New Testament. Grand Rapids: Baker, 2003.

Himawan, Karel Karsten, Bambling, Matthew dan Edirippulige, Sisira. "What Does It Mean to Be Single in Indonesia? Religiosity, Social Stigma, and Marital Status Among NeverMarried Indonesian Adults." SAGE Open (Juli-September 2018): 1-9. https://doi. org/10.1177/2158244018803132.

-. "The Asian Single Profiles: Discovering Many Faces of Never Married Adults in Asia," Journal of Family Issues (2018): 1-23. https://doi. org/10.1177/0192513X18789205.

Horsley, Richard A. "Spiritual Marriage With Sophia." Virgiliae Christianae 33, no. 1 (1979): 46-54.
Huffman, Norman A. "Did Jesus or Paul Marry?" Journal of Ecumenical Studies 5, no. 4 (1968): 741-744.

Hurd, John. The Origin of 1 Corinthians. London: SPCK, 1965.

Razafiarivony, Davidson. "Marriage and Sexual Obligations according to Paul in 1 Corinthians 7:1-7," IOSR Journal of Humanities and Social Science 22 No. 8 (Agustus 2017): 58-70.

Thiselton, Anthony C. The First Epistle to the Corinthians. The New International Greek Testament Commentary. Grand Rapids: W. B. Eerdmans, 2000.

Tridarmanto, Yusak. "Menikah? Baik. Tidak? Lebih Baik: Suatu Telaah Teologis atas Respon Rasul Paulus terhadap Tendensi Hidup Selibat di dalam 1 Korintus 7." Gema Teologi 33, no. 1 (April 2009): 1-17.

Valentine, Katy E. "1 Corinthians 7 in Light of Ancient Rhetoric of Self-Control," Review and Expositor 10 (2013): 577-589.

Vantassel, Stephen. "Celibacy: The Forgotten Gift of the Holy Spirit." The Journal of Biblical Counseling 12, no. 3 (1994): 20-23.

Wehr, Kathryn. "Virginity, Singleness and Celibacy: Late Fourth-Century and Recent Evangelical Visions of Unmarried Christians." Theology \& Sexuality 17, no. 1 (Januari 2011): 76-99. https://doi. org/10.1558/tse.v17i1.75.

Winter, Bruce W. "Puberty or Passion? The Referent of $v \pi \varepsilon \rho \alpha \kappa \mu о \sigma$ in 1 Corinthians 7:36. " Tyndale Bulletin 49, no. 1 (1998): 71-89. 